\title{
WILLA CATHER
}


Women Writers

General Editors: Eva Figes and Adele King

Published titles:

Margaret Atwood, Barbara Hill Rigney

Anne Brontë, Elizabeth Langland

Charlotte Brontë, Pauline Nestor

Emily Brontë, Lyn Pykett

Fanny Burney, Judy Simons

Willa Cather, Susie Thomas

Sylvia Plath, Susan Bassnett

Christina Stead, Diana Brydon

Eudora Welty, Louise Westling

Women in Romanticism, Meena Alexander

Forthcoming:

Fane Austen, Meenakshi Mukherjee

Elizabeth Barrett Browning, Marjorie Stone

Elizabeth Bowen, Phyllis Lassner

Iry Compton Bumett, Kathy Gentile

Colette, Diana Holmes

Emily Dickinson, Joan Kirkby

George Eliot, Kristin Brady

Mrs Gaskell, Jane Spencer

Doris Lessing, Barbara Hill Rigney

Katherine Mansfield, Diane DeBell

Christina Rossetti, Linda Marshall

fean Rhys, Carol Rumens

Stevie Smith, Catherine Civello

Muriel Spark, Judith Sproxton

Edith Wharton, Katherine Joslin

Virginia Woolf, Clare Hanson 


\section{Women Writers}

\section{Willa Cather}

Susie Thomas

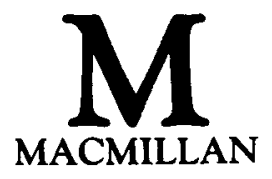




\section{(C) Susie Thomas 1990}

All rights reserved. No reproduction, copy or transmission of this publication may be made without without permission.

No paragraph of this publication may be reproduced, copied or transmitted save with written permission or in accordance with the provisions of the Copyright Act 1956 (as amended), or under the terms of any licence permitting limited copying issued by the Copyright Licensing Agency, 33-4 Alfred Place, London WCIE 7DP.

Any person who does any unauthorised act in relation to this publication may be liable to criminal prosecution and civil claims for damages.

First published 1990

Published by

MACMILLAN EDUCATION LTD

Houndmills, Basingstoke, Hampshire RG21 2XS

and London

Companies and representatives

throughout the world.

Phototypeset by Gecko Limited, Bicester, Oxon

British Library Cataloguing in Publication Data

Thomas, Susie

Willa Cather. - (Women writers).

1. Fiction in English. American writers. Cather,

Willa, 1873-1947

I. Title II. Series

$813^{\prime} .52$

ISBN 978-0-333-42361-5 ISBN 978-1-349-20407-6 (eBook)

DOI $10.1007 / 978-1-349-20407-6$

PPL: G/90188 


\section{Contents}

Acknowledgements

Editors' Preface

Introduction

vii

ix

1

1. Willa Cather 1873-1947

4

2. To Bayreuth and back again: The Troll Garden, The Song of the Lark, One of Ours, Uncle Valentine 20

3. From horse opera to homesteads: O Pioneers! 54

4. The golden girl of the West: My Ántonia 76

5. Time's fool and A Lost Lady 98

6. To speak of the woe that is in marriage: The Professor's House

7. The chemistry of colour: Death Comes for the Archbishop, Shadows on the Rock

8. Testimony: Obscure Destinies, Sapphira and the Slave Girl, The Old Beauty and Others

Notes

Bibliography

Index 


\section{Acknowledgements}

I would very much like to thank Professor Alan G. Hill of Royal Holloway and Bedford New College, London University and $\operatorname{Dr} M$. Cotsell of Delaware University, for their criticism and continued encouragement. I would also like to thank Stewart Spencer for his helpful comments on Willa Cather and Wagner.

Due to stipulations in Cather's will, which prohibit the publication of her letters, it is difficult to gain access to her correspondence. I would like to acknowledge a grant from London University's Central Research Fund which enabled me to visit America for this purpose. Of the many libraries which responded to my enquiries about Cather material I am particularly grateful to: Amherst College Library; Bailey/Howe Library, University of Vermont; Clifton Waller Barret Library, University of Virginia; Beinecke Library, Yale University; Bentley Historical Library, University of Michigan; Boatwright Memorial Library, University of Richmond; Butler Library, Columbia University; Houghton Library, Harvard University; Huntington Library; Nebraska State Historical Society; Newberry Library; New York Public Library; William R. Perkins Library, Duke University; Phillips Exeter Academy; Pierpont Morgan Library; Princeton University Library; Sterling Memorial Library, Yale University; Willa Cather Pioneer Memorial Museum and Educational Foundation.

The author and publishers wish to thank the following who have kindly given permission for the use of copyright material: Virago Press Ltd, with Houghton Mifflin Company for extracts from Song of the Lark 
by Willa Cather, 1982, 1986. Revised edition copyright (C) 1937 Willa Sibert Cather, revised 1965 by Edith Lewis, and My Antonia by Willa Cather. Copyright (C) 1918 by Willa Sibert Cather, renewed 1955 by the Executors of the Estate of Willa Cather; and with Alfred Knopf, Inc, for extracts from Death Comes to the Archbishop by Willa Cather. Copyright (C) 1927 by Willa Sibert Cather, renewed 1955 by the Executors of the Estate of Willa Cather; $A$ Lost Lady by Willa Cather. Copyright (C) 1923 Willa Sibert Cather, renewed 1951 by the Executors of the Estate of Willa Cather; and The Professor's House by Willa Cather. Copyright (C) 1925 by Willa Sibert Cather, renewed 1953 by the Executors of the Estate of Willa Cather.

Every effort has been made to trace all the copyright holders, but if any have been inadvertently overlooked the publishers will be pleased to make the necessary arrangement at the first opportunity. 


\section{Editors' Preface}

The study of women's writing has been long neglected by a male critical establishment both in academic circles and beyond. As a result, many women writers have either been unfairly neglected, or have been marginalised in some way, so that their true influence and importance has been ignored. Other women writers have been accepted by male critics and academics, but on terms which seem, to many women readers of this generation, to be false or simplistic. In the past the internal conflicts involved in being a woman in a male-dominated society have been largely ignored by readers of both sexes, and this has affected our reading of women's work. The time has come for a serious re-assessment of women's writing in the light of what we understand today.

This series is designed to help in that re-assessment. All the books are written by women, because we believe that men's understanding of feminist critique is only, at best, partial. And besides, men have held the floor quite long enough.

Eva Figes

Adele King 
For my mother and in memory of my father. 